\title{
Malaysia: From Hub to Exporter of Higher Education and Implications
}

\author{
Yuk Fong Chin \\ Vice-Chancellor \\ North Borneo University College \\ Sabah, Malaysia
}

\begin{abstract}
The purpose of this paper is to discuss the factors that have turned Malaysia into an exporter of higher education as well as their implications. Malaysia has been striving to develop a world-class higher education system that will help transform its production-based economy into a knowledge-based economy by 2020. In the 1990s, public universities were corporatized to become less dependent on government subsidies. With the passing of the 1996 Private Higher Education Act, private higher education began to expand in Malaysia. Currently, Malaysia is a highly favoured study destination for international students from India, Bangladesh, Africa, the Middle East and Eastern Europe. Malaysia's political stability and its open-market economy have provided a secure environment for international students. Further, the government has been clear about its intention of making higher education an export industry. It has adopted several measures to ensure the orderly maintenance of education quality through the National Accreditation Board, and subsequently, the Malaysian Qualifications Agency. Since the demand for higher education will continue to increase in the next 20 years, Malaysian higher institutions of learning will be able to widen their market share while strengthening the government's strategy to make higher education an export industry.
\end{abstract}

Keywords: Malaysia, exporter of higher education, international hub, factors, quality control

\section{Introduction}

Malaysia is steadily gaining recognition of its higher education system that helps strengthen its aim to become a global education destination by 2025. The2015-2025 Malaysia Education Blueprint for Higher Education aims to attract 250,000 international students by 2025. A challenging global economy and changing geopolitical trends have encouraged an increasing number of international students to pursue higher education in Malaysia, allowing the nation to capitalise on its strengths in higher education to increase international student enrolment. International students currently contribute about RM 5.9 billion annually to the Malaysian economy and are expected reach RM 15.6 billion by 2020. They not only contribute to the Malaysian economy, but they also promote cultural exposure, competitiveness and networking that benefit both students and the community (Jusoh, 2017). The purpose of this paper is to discuss the factors that have turned Malaysia from a hub to an exporter of higher education in Asia and implications of the transition.

Malaysia aims to become the world's sixth biggest higher education exporter by 2020 with a target of 200,000 international students. To enhance Malaysia's reputation as an attractive study destination, the government has taken several steps; for example, it has encouraged the private sector to help provide industry-relevant education and invested in niche study areas, such as finance, banking and executive education. It has also attracted several international universities to set up branch campuses in strategic locations (ICEF, 2012).

\section{History of private higher education}

In the 1990s, private higher education in Malaysia adopted the model of Western countries and several international campuses were set up to cater for mostly local students and some international students. Malaysia has been viewed as an educational hub by international partners that are keen to collaborate with local private education institutions for a win-win situation, thus promoting cross-border, borderless and transnational higher education. (Arokiasamy, 2010).

In 1995, about 20 percent of the Malaysian students were studying abroad, costing the country about US\$800 million in currency outflow and constituting nearly 12 percent of its current account deficit. The government regarded the private sector as the primary means to reduce currency outflow and to transform the country into a net exporter of higher education (Ismail 1997). In 1996, through the Private Higher Educational Institutions Act 1996, the government began to encourage the private sector to assume a complementary role in providing higher education. By 1999, about 203,391 Malaysian students were enrolled in private institutions, including three international university branch campuses and more than 400 private colleges in the country (Arokiasamy, 2010). 
In the 1990s, new private universities and international branch campuses could only be established with permission from the Ministry of Education. The 1996 Private Higher Educational Act was amended in 2003 in response to new challenges in private higher education. The amended act permits the establishment and upgrading of private universities, university colleges and branch campuses in Malaysia; subsequently, several private higher educational institutions were subsequently upgraded to university colleges (Arokiasamy, 2010).

\section{Malaysian exporter of higher education: Educity Iskandar}

Increasing involvement of the private sector in higher education over the last few decades has contributed significantly to Malaysia's socioeconomic progress. Private higher education has fostered the progress, stability and harmony of Malaysia for the past 25 years. In 2015, Malaysia's Educity Iskandar opened as a full campus with several international universities, such as Newcastle, Southampton and Reading. Three of the international universities that became part of EduCity were from the UK, showing that Malaysia and the UK were growing closer in terms of educational initiatives. Educity is one of Malaysia's main efforts to attract international students; it has become the hub of high-tech industry and many companies are now collaborating with Educity and employing its graduates.

Further, EduCity emphasises the development of research infrastructure to become a regional centre of excellence and the central node for an international network of academic institutions, companies and services. It enables international students to work in an integrated environment that combines academic excellence and entrepreneurship (ICEF, 2012).

\section{Kuala Lumpur education hub}

Besides EuduCity, Nilai, Kuala Lumpur is another hub that welcomes both international and local educational institutions. In 2013, Manipal International University, headquartered in India, established its campus here. This university enrols 20,000 students in business, engineering, finance and science. Another key player at Nilai is INTI International University and Colleges. INTI is the first private university in Malaysia that offers a bachelor degree in traditional Chinese medicine characterised by both eastern and western curricula (Abu Hassan Asari, Muhamad, \& Megat Khalid, 2017).

\section{Limkokwing University of Creative Technology (LUCT)}

Limkokwing University of Creative Technology (LUCT) started as a private college in 1991, but it was upgraded to full university in 2007. It currently has more than 30,000 international students from 150 countries, enrolled in 12 campuses worldwide. LUCT initially exported its programs by opening its first international branch in Botswana in 2007, followed by the United Kingdom in the same year. Additionally, it was the first university from the Commonwealth that had successfully built an off-shore campus in the UK (Abu Hassan Asari, Muhamad, \&Megat Khalid, 2017).

\section{Factors influencing Malaysia as an Exporter of Higher Education}

As aforementioned, the 1997 financial crisis compelled Malaysia to modify its view on higher education whereby private institutions were required to deal with the situation. The 1996 Private Higher Educational Institutions Act and the 1996 National Accreditation Board Act were passed to regulate private higher educational institutions that had mushroomed in the mid-80s. During this period, more than 580 public and private institutions offered tertiary programs in Malaysia; however, private institutions were only allowed to confer certificates and diplomas (Abu Hassan Asari, Muhamad, \& Megat Khalid, 2017).

Since the 1990s, private higher educational institutions no longer complement the public ones due to their medium of instruction. English is used to generate twinning programs between private higher educational institutions and international universities. In addition, study terms such as $2+2$ and $3+1$ have become popular marketing strategies to attract prospective undergraduates among locals. The $3+1$ programs allow students to have their first three years in Malaysia, with the remaining year to be completed in the twinning institution overseas. Degree are conferred by the respective twinning institutions (Abu Hassan Asari, Muhamad, \& Megat Khalid, 2017).

\section{Ninth Malaysian Plan}

Malaysia as the regional centre for higher education was tabled in the Ninth Malaysian plan (2006-2010). Besides private institutions, technical providers have been urged to offer more seats for international students. Further, the National Higher Education Action Plan was launched to systematically manage higher education. It emphasises internationalisation in various aspects of higher education, including academia, programs, infrastructure, environment, networking, research and development, publications and benchmarking. Intensifying internationalization became one of the thrusts in attracting more students to study in Malaysia (Abu Hassan Asari, Muhamad, \& Megat Khalid, 2017). 
Further, higher education became one of Malaysia's 2010 national key economic areas and the educational sector is expected to contribute RM60.7 billion of the nation's gross national income in 2020. Out of 13 entry point projects, seven were linked to higher education, while championing Malaysia's international education brand became the $12^{\text {th }}$ entry point project (Abu Hassan Asari, Muhamad, \& Megat Khalid, 2017).

\section{Market liberalisation}

By 2010, there were 476 private higher institutions of learning in Malaysia with more international universities establishing their off-shore campus in Malaysia. Market liberalisation has allowed international providers to participate in Malaysian higher education. One of the reasons was the increase in the number of 'glocal' students who aspire globally, but study locally. Students now have a chance to study at their preferred foreign university in their home country or another country in the same region (Abu Hassan Asari, Muhamad, \&Megat Khalid, 2017).

\section{Government-linked companies}

The Malaysian government has encouraged government-linked companies (GLCs) to establish private universities. Consequently, Universiti Teknologi Petronas was established by Petronas, a leading company in the oil and gas industry. Multimedia University was established by Telekom Malaysia Berhad, while Universiti Tenaga Nasional by Tenaga Nasional Berhad. Although the major programs of these universities are based on their parent-funder core business, other fields such as business, management and finance are also offered (Abu Hassan Asari, Muhamad, \&Megat Khalid, 2017).

\section{Lower currency value}

The 1997 Asian financial crisis caused the Malaysian economy to plummet, especially in manufacturing and construction sectors; however, the opposite scenario happened in higher education. Lower ringgit value had led to increased international enrolments in Malaysian private higher educational institutions and most of the students came from the developing bloc. Therefore, Malaysian higher education has been identified as a sustainable economic commodity (Abu Hassan Asari, Muhamad, \& Megat Khalid, 2017).

\section{Education to promote socioeconomic growth}

Malaysia has successfully harnessed its educational sector to fuel socioeconomic growth. The 1997 economic downturn encouraged this nation to strengthen its educational system to counter the adverse impact. Counter-measures included (1) convincing students to study in Malaysia rather than overseas, (2) establishing twinning programmes with reputable international universities, (3) attracting international students to study in Malaysia and (4) establishing branch colleges and universities in other countries (ICEF, 2012).

\section{Knowledge and innovation}

Malaysia has been successful in establishing its reputation as a hub for higher education for students from across Asia and the rest of the world. Higher education has become the top priority for Malaysia to progress as it acknowledges that the global economy is now increasingly driven by knowledge and innovation. Its future economic growth depends on its success in innovation through quality education. In short, higher education is now the prime mover of Malaysia's socioeconomic development (ICEF, 2012).

\section{Favourable educational destination}

A 2014 UNESCO report on higher education identified several reasons for international students to choose Malaysia as their educational destination, including cultural comfort, cost, medium of instruction and quality of life. Malaysia provides a friendly environment for international students; besides, Malaysians are very understanding and respectful due to the multiracial and multireligious composition of their nation. Further, higher education in Malaysia is not only more affordable compared to Western countries, but the quality also represents value for money (Jusoh, 2017).

In 2016, the British Council reported that Malaysia was the best performer on openness to international higher education among 26 countries. It scored the highest marks in openness and international mobility policies, quality assurance and degree recognition and access and sustainability, thus reflecting its commitment to global higher education. These milestones were due to the liberalisation of Malaysian higher education that began in early 1980s(Jusoh, 2017). 
The 2017 QS Best Student Cities survey showed that Kuala Lumpur was the world's most affordable city for international students; moreover, the2017 QS World University Rankings by Subject revealed that Malaysian universities were in the world's top 50 for 11 subjects, including mechanical, electrical and chemical engineering, hospitality and tourism, theology, and development studies. Another 52 subjects in Malaysian universities ranked among the world's top 100 (Jusoh, 2017).

\section{Student-friendly nation}

Malaysia is undoubtedly a very attractive education destination for international students. It is student-friendly because international students are encouraged to become part of its social and economic fabric. Many student-friendly services and opportunities are made available, from industrial internships and non-governmental organisations to volunteerism. In sum, Malaysia offers international students a life-defining experience, filled with excitement and opportunity. Malaysians are receptive of this global era and have an adaptable mindset to the opportunities brought about by technological advances (Jusoh, 2017).

In 2017, public universities allocated five per cent of places in their medal, pharmacy, and dentistry programmes to international students. This is a great opportunity for international students as these courses are delivered by top-notch faculty and specialists. For example, Universiti Malaya's medical faculty has been ranked $31^{\text {st }}$ in the world for its academic reputation, putting it on a par with Duke University, while Universiti Kebangsaan Malaysia and Universiti Sains Malaysia have been ranked 49th and 52nd, respectively (Jusoh, 2017).

\section{Good rankings}

Additionally, Malaysia more than 10 top international university branch campuses, including Monash and Nottingham (which are in the world's top 100) and the Asia School of Business in collaboration with MIT Sloan Management School. Therefore, international students have a good range of quality choices in their chosen fields. Malaysia is also focusing on increasing intake at postgraduate levels, including Master's, $\mathrm{PhD}$ and Post-doctoral. In 2017, about 23 per cent of all international students in Malaysian universities are pursuing postgraduate degrees, indicating adequate and competent research opportunities for international students (Jusoh, 2017).

\section{Improved international student management}

The Malaysian government has been striving to improve international student management. For instance, student visas are now issued for the duration of the programme rather than yearly, while visa applications can be made online and tracked in realtime. Moreover, more family-friendly regulations for international students have been introduced (Jusoh, 2017).

In 2013, the Education Malaysia Global Services (EMGS) was launched to ease up the applications for Malaysian higher education institutions. Instead of dealing with several government agencies that may cause delay in admissions, prospective students just need to deal with this single EMGS agency and completed student visa applications will be processed in 14 days. This agency helps reduce last-minute approvals that had previously reduced 15 percent of international admissions. Therefore, it improves the image of Malaysia as a major exporter of global higher education. Problems such as visa abuse, drug abuse and anti-social activities among international students in Malaysia are handled by both the EMGS and Immigration Department. Better hospitality services are now offered to the international students (Abu Hassan Asari, Muhamad, \& Megat Khalid, 2017).

In 2014, the total number of international students in Malaysia was 107, 838 and about 70 percent were enrolled PrHEIs. Indonesia, Iran, Iraq, Nigeria and China were the top five importers. One of the possible factors was the university's academic calendar in Malaysia; to streamline the academic calendar between Malaysia and other countries, the July intake for first-degree programs was changed to September starting 2013. The new academic calendar allows international applications to be processed in time without waiting for another academic year (Abu Hassan Asari, Muhamad, \& Megat Khalid, 2017).

\section{Rapid information dissemination}

In 1998, StudyMalaysia.com was launched as a one-stop portal that offers the quickest way to obtain information on educational providers, academic programs, accommodation, entry requirements, financial assistance, and other things that are related to Malaysian higher education. It also includes immigration procedures, country's background, and an online help-desk (Abu Hassan Asari, Muhamad, \& Megat Khalid, 2017). In 2004, the Ministry of Higher Education (MoHE) Malaysia was formed to identify the status quo and proposing the betterment for Malaysian higher education. MoHE then established several Malaysia Education promotion centres overseas, including Jakarta, Beijing, Dubai and Ho Chi Minh City (Abu Hassan Asari, Muhamad, \& Megat Khalid, 2017). 


\section{Program flexibility}

Program flexibility is another comparative advantage for private institutions of higher learning. To fill up vacancies in Cyberjaya in the 90s, private institutions of higher learning started offering IT programs that in turn increased their enrolments several times. Such flexibility continues as they strive to introduce more delivery methods, such as distance learning, open learning and franchise programs. This flexibility could be driven by the profit-seeking endeavours of private institutions of higher learning (Abu Hassan Asari, Muhamad, \& Megat Khalid, 2017).

\section{Community engagement}

A higher education specialty that Malaysia emphasises is the concept of community engagement. In early 2012, Universiti Kebangsaan Malaysia hosted the launch of AsiaEngage that serves as an umbrella organisation for community-engaged universities. Asia Engage emphasised that being active, responsive and engaged with communities is integral to the purpose and strength of universities. It encourages universities to partner with both governments and NGOs to engage with communities, for example, by conducting research in the communities and learning from their perspectives. Local people can offer relevant knowledge and help students put theories into practice (ICEF, 2012).

\subsection{Implications}

\section{Impact of globalisation}

Higher education is a major variable in overcoming the challenges of globalisation that has increased transnational travel by erasing territorial boundaries electronically or through physically-based campuses. Exporting higher education services emerged in the late 1980s and early 1990s, but it is now becoming a global, market-oriented, and private industry in Malaysia. Malaysia has established international networks by having academic offices overseas and by collaborating with partner institutions to increase student enrolment. It is now one of the largest providers of private higher education to overseas students in Asia (Arokiasamy, 2010).

Private higher education in Malaysia has moved from a peripheral to a central position in its government's response to globalisation. Globalisation is a key factor influencing Malaysian institutions of higher learning partly as subjects or key agents. They help promote a knowledge society that deals symbolic goods, worldwide brands and images as commodities and scientific know-how (Arokiasamy, 2010).

\section{Marketisation and internationalisation}

Malaysian policies on marketisation and internationalisation of higher education have been moving toward several Asian countries, such as India, China and Indonesia. Since Asia will dominate the global demand for international higher education for the next two decades; demand for higher education in Malaysia will increase tremendously. Demand is projected to increase from 1.8 million in 2000 to 7.2 million international students in 2025, with Malaysia representing a significant percentage of the total global demand for higher education (Arokiasamy, 2010).

\section{Decontextualised and human capital-oriented}

Globalisation compels the Malaysian educational system to produce decontextualised and human capital-oriented knowledge. Highly globalised economies require graduates who are creative, innovative and flexible in solving problems. Nevertheless, Malaysia, being multicultural, also emphasises local and contextualised knowledge while adopting the world model. Further, to meet the demands of changing market economies, Malaysia strives to evolve from a production-based to an innovative, knowledge-based economy that requires a highly skilled and knowledgeable workforce. Development of this critical workforce requires greater accessibility and flexibility in terms of higher education (Arokiasamy, 2010).

\section{Access and equality}

The rapid increase of international students in Malaysian private institutions of higher learning and other international comparatives has made Malaysia a significant contender as an international market for international students. However, it must address some crucial issues related to higher education. Due to globalisation, higher education systems have become sites for various kinds of competition in various societies. Competition for access and equality has become inevitable; it requires the Malaysian government to examine various strategies so as to include all social, ethnic and racial groups, while striving to achieve the requirements of the emerging labour market. Malaysia serves an example to understand the experiences of developing countries that have adopted neo-liberal economic reforms to cope with the challenges of globalisation. Overall, globalisation has driven Malaysia to start policy reforms to achieve excellence, relevance and marketability of its higher education system (Arokiasamy, 2010). 


\section{Financial implications}

In the 90s, many middle-class families were unable to send their children overseas due to economic recession. To address the financial concerns of the middle-class families, the Malaysian government responded by increasing privatisation with the intention of attracting interantional investment and students into Malaysia (Arokiasamy, 2010).

Financial constrictions have led to greater privatisation of higher education in Malaysia as there has been a substantial reduction in government funding of higher education; therefore, higher educational institutions have to reshape their internal organisation and practice. Student grants have been replaced by loans while fees have been introduced for undergraduates. To earn revenue, higher educational institutions are now increasingly dependent on their entrepreneurial capacity to recruit students and to raise money from research grants, contracts and endowments. (Arokiasamy, 2010).

\section{Impact of information technology}

The information age has significantly changed the higher education scenario in Malaysia; it has promoted higher education with better communication, storage and knowledge retrieval, greater access to databases, websites and other IT-based products. Higher education researchers have become increasingly dependent on the Internet to disseminate their work, while many higher educational institutions have started to use IT for program delivery, with distance education becoming increasingly popular in Malaysia (Arokiasamy, 2010).

\section{Complexities and nuances of the Internet}

The Internet allows students and highly-qualified personnel to easily cross borders, further promoting Malaysia as an exporter of higher education. The major implication is that Malaysia should recognise the complexities and nuances of the modern context to create a global academic environment that ensures favourable academic relationships. Another implication is that Malaysia should strive to reduce academic inequalities to ensure that globalisation does become the neocolonialism of the $21^{\text {st }}$ century (Arokiasamy, 2010).

\section{Profit and communal aspirations}

Higher education institutions in Malaysia should not be motivated by only profit, but also communal aspirations of civic engagement. Academic values and civic missions in higher education institutions should also address human rights, multilateralism and global citizenship. Higher education plays a key role in advancing the cause of humanity and citizenship; international education should be a trading game for students' self-enrichment. Malaysian higher education strives to realize the positive impact of globalization, linking academia to social change and creating an influential community for a sustainable future (Arokiasamy, 2010).

\section{Reduction in National Higher Education Fund Corporation (PTPTN) loans}

In 2015, the number of new students receiving full financing from the National Higher Education Fund Corporation (PTPTN) was reduced by 43 percent. Only those from family registered for BR1M would receive full financing. PTPTN needs RM 5 billion to continue to operate annually, while loan repayment rate is low, which has adversely affected its financial operations. To overcome funding constraints and reduce the number of new borrowers, PTPTN had to reduce loan amounts (Hoh, 2015).

\section{Reduction in technical and vocational education}

Starting from 2019, more than 20,000 technical and vocational education and training (TVET) private college students may have to stop their studies due to a lack of funds in the Skills Development Fund Corporation (SDFC). In the last four years, the Human Resources Ministry has consistently shrunk the allocation to SDFC and it now stands at 60 per cent less. Most of the students are from the lower income group and so had no other source of financing other than loans from SDFC (Rusman, 2018).

\section{Decrease in educational funding}

A decrease in educational funding implies that private institutions of higher learning in Malaysia can no longer depend on local students and government funding as a source of revenue. Such decease will undoubtedly lead to a serious drop in the enrolment of local students in private institutions of higher learning, thus compelling these institutions to seek revenue from other sources, such as by increasing international student enrolments and collaborating with international universities and colleges.

\section{Quality control and assurance}

Recently, several private higher education institutions have acquired full university or university college status, giving them the power to award their own degrees. 
Some can even award research degrees, while others enable students to get two degrees, one from the local institution and another from a partner university overseas. This validates that the local degree is at par and of the same academic rigour and standard as its own (Teng, 2016).

\section{Malaysian Qualifications Agency}

The Malaysian Qualifications Agency (MQA) has developed a robust and comprehensive accreditation and regulatory framework for all private higher education providers. The route to quality is evolving continually and Malaysian private higher education institutions will have to continue to be at the forefront of adopting best practices. Quality evaluation audits such as the Malaysia Quality Evaluation System rating for private colleges and the Rating System for Malaysian Higher Education Institutions rating for universities and university colleges are in place to ensure compliance, governance and the quality of the learning and teaching standards (Teng, 2016).

\section{References}

Abu Hasan Asari, F. F., Muhamad, S., \&Kalid, P. Z. M. (2017). Globalisation and liberalisation of Malaysian higher education. ESTEEM Journal of Social Sciences and Humanities, 1, 1-14.

Arokiasamy, A. R. A. (2010). The impact of globalisation on higher education in Malaysia. Genting Inti International College, Pahang, Malaysia.

Hoh, K. S. (2015). Number of students receiving PTPTN loan to be reduced by 43\%. The Sunday Daily, newsdesk@thesundaily.com.

ICEF (2012). Malaysia aims to be sixth-largest education exporter by 2020, http://monitor.icef.com/2012/05/malaysiaaims-to-be-sixth-largest-education-exporter-by-2020/.

Ismail, R. (1997). The role of the private sector in Malaysian education. Educational Challenges in Malaysia: Advances and prospects. Clayton: Monash Asia Institute.

Jusoh, I. (2017). Turning the world towards Malaysian education, New Strait Times, https://www.nst.com.my/turningworld-towards-malaysian-education.

Teng, R. (2016). The quality of private higher education in Malaysia. The Edge Financial Daily, http://www.theedgemarkets.com/article/quality-private-higher-education-malaysia.

Rusman, A. (2018). 20,000 TVET students may have to stop studying. New Straits Times, https://www.nst.com.my/news/nation/2018/10/419578/20000-tvet-students-may-have-stop-studying.

Chin, Y. F.(2019)Malaysia: From hub to exporter of higher education and implications.

International Journal of Business and Social Science, 10 (2), 1-7 